Proceeding of the Eleventh Veterinary Scientific Conference, 2012; 347 -354.

\title{
Study the influence of some Listeria monocytogenes antigens on the side effects of Mitomycin C
}

Ibrahim Z.I. ${ }^{1}$, Al-Wan . M. J. ${ }^{1}$ and Nahi Y. Yaseen ${ }^{2}$

1- Department of Pathology and Poultry diseases, College of Veterinary Medicine, University of Baghdad 2-Iraqi Center for Cancer and Medical Genetic Research

E-mail zainabalrubaei@yahoo.com

\section{Summary}

For studying in vivo influence of immune responses on side effects of Mitomycin $\mathrm{C}$ (MMC),Sixty-five male-white mice were divided to nine groups ;1st group inoculated MMC,I.P, $0.4 \mathrm{mg} / \mathrm{ml}, 2$ doses weekly/4 weeks;2nd to 7 th groups immunized S/C with $L M$ Ags $(25 \mathrm{mg} / \mathrm{ml})$ protein concentration $0.4 \mathrm{ml}$, 2doses $/ 2$ weeks intervals;2nd and 3rd groups immunized CFLMAgs and CFLMAgs-MMC in 3rd group; also 4th and fifth groups but immunized with WSLMAgs; 6th and 7th groups inoculated with $0.4 \mathrm{ml}$ Attenuated $L M$ (LaLMAgs), 7th group immunized-MMC treated. Post-immunization, 5 animals sacrificed from 1-7groups and negative control to study the cellular and humoral immunity as well as bone marrow taken to cytogenic examination ,other animals from 1-7 groups and 8th group challenged with $0.4 \mathrm{ml}$ of (ViLM) containing $\left(1 \times 10^{9} \mathrm{CFU} / \mathrm{ml}\right)$ of $)$, the animals of negative group inoculated $0.4 \mathrm{ml}$ of sterile PBS,S/C.Results; showed high mean values of IFN-y and IgG1 in animals immunized with LM.Ags, while MMC decreased levels of IFN-y and IgG1and MI\%, increased chromosomal aberrations and micronucleus while decreased in immunized also immunized-MMC treatment, immunized animals show increased MI\%.The suppurative pathological lesions and suppurative granulomatous lesions were appeared clear in tissue sections of internal organs in animals of positive control,decreased severity in immunized,immunized-MMCtreated especially with LaLM immunization.

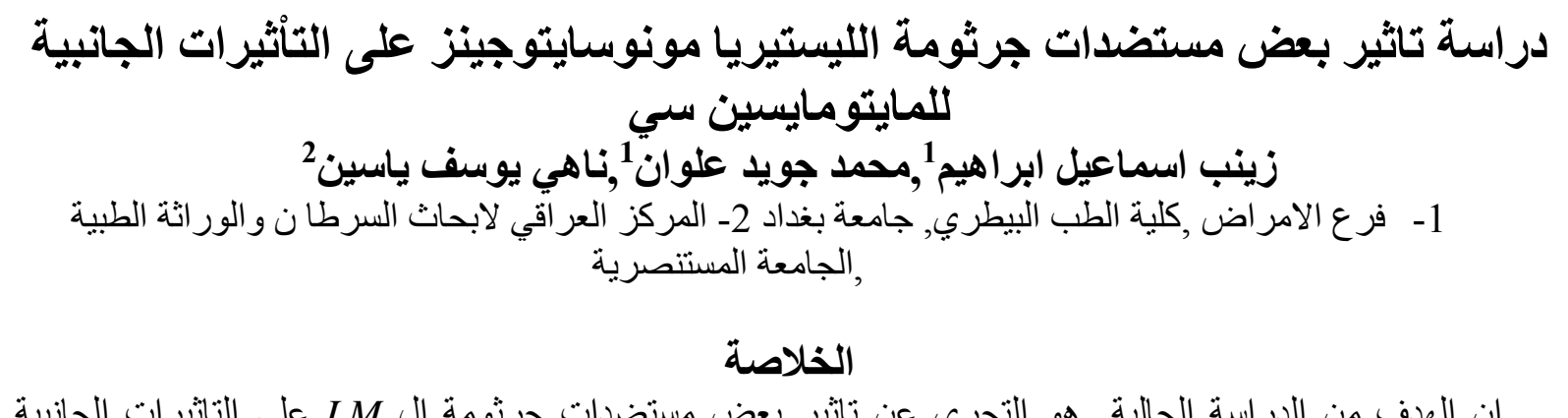

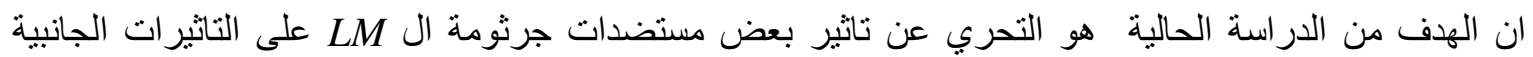

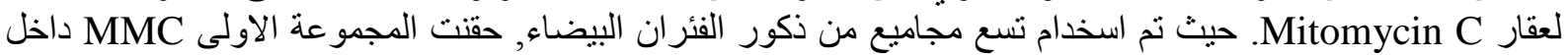

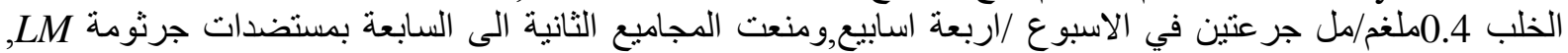

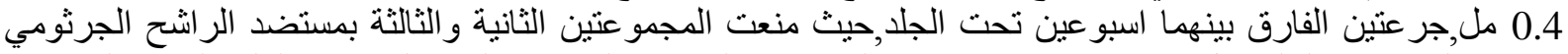

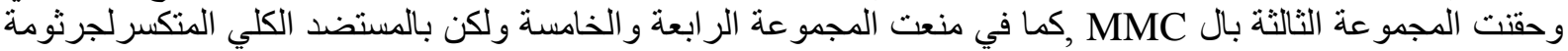

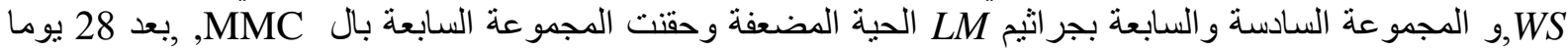

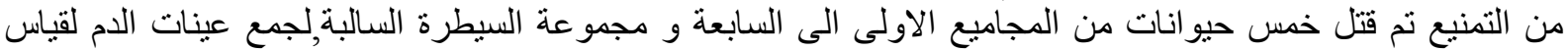

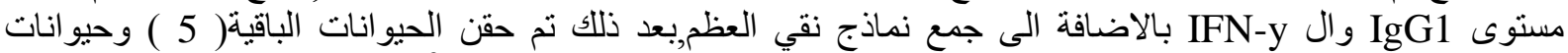

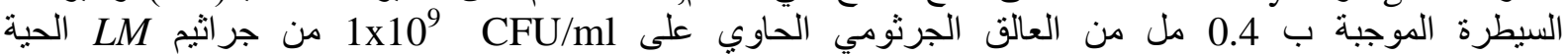

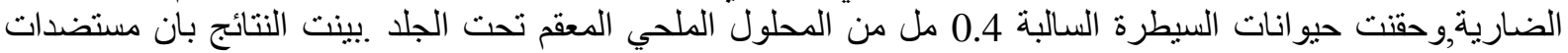

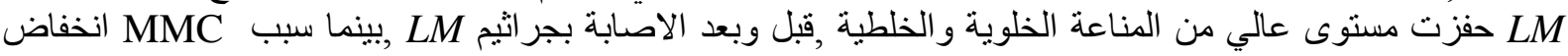

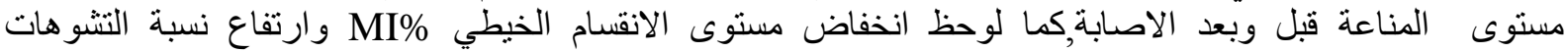

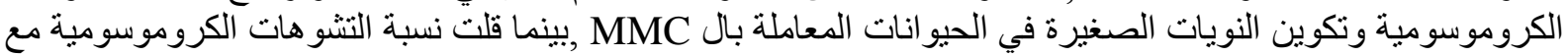

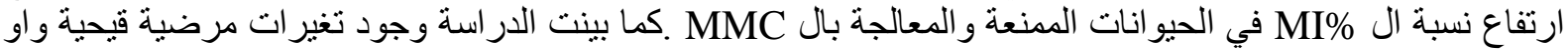

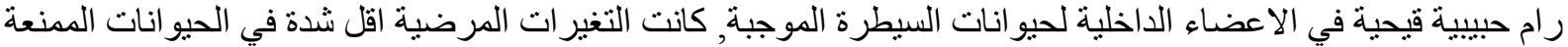
و الممنعة و المعاملة بال MMC بعد الاصابة وخاصة في الحيو انات الممنعة بجر اثيم LM المضعفة. 


\section{Introduction}

Mitomycin $\mathrm{C}$ is a cytotoxic drug in clinical chemotherapy regiments for the treatment of various carcinomas $(1,2,3,4)$ for a more than 30 years, it is cytotoxicity due primarily to the formation of DNA adducts-in particular; DNA interstrand cross-link (ICL) (5). It is also used in combination with other antitumour agents in palliative treatment of many advanced cancers or cancers that have become resistant to other (6).

The cytogenic studies revealed that MMC frequently produce chromatid exchanges in human cells, particularly human chromosomes (1,9 and 16) are frequently involved in so called quadriradicals (7). Very few workers have studied the influences of stimulated immune system against the cytogenetic effects of MMC on bone marrow cells of mice, hence, the present study was undertaken to determine the influences of some Listeria monocytogenes antigens on mitotic activity and chromosomal aberrations in mice immunized-treated MMC and study the pathological changes.

Experimental design: Sixty-five ( $\mathrm{n}=65)$ of white male mice aged (7-8 weeks), divided randomly into seven groups and treated as following:

$\mathbf{1}^{\text {st }}$ group: $(\mathrm{n}=10)$ inoculated with $0.4 \mathrm{ml}(0.4 \mathrm{mg} / \mathrm{ml})$ MMC, I.P., 2 doses weekly $/ 4$ weeks. $\mathbf{S}^{\text {nd }}$ group: $(\mathrm{n}=10)$, immunized with $0.4 \mathrm{ml}$ of Culture Filtrate Listeria monocytogenes antigens (CFLMAgs) $(25 \mathrm{mg} / \mathrm{ml}), \mathrm{S} / \mathrm{C}, 2$ doses, 2 weeks intervals. $3^{\text {rd }}$ group: $(\mathrm{n}=10)$ immunized as in 2nd group, at the same time inoculated with MMC as in the 1 st group. $4^{\text {th }}$ group: $(n=10)$, immunized as the 2nd group but with Whole-Sonicated LM.Ags (WSLM.Ags). $5^{\text {th }}$ group: $(\mathrm{n}=10)$ immunized as in 4th group and treated with $\mathrm{MMC}$ as the in 1 st group. $6^{\text {th }}$ group: $(\mathrm{n}=5)$ as positive control. $7^{\text {th }}$ group: $(\mathrm{n}=10)$ as negative control.

At day 28 post-immunization, skin test was done and five animals from 1st, 2nd, 3rd, 4th, 5th and 7th groups were sacrificed and collect blood to determined IFN-y and $\operatorname{IgG}_{1}$ concentrations and bone marrow for cytogenic analysis (8), the remaining five animals as well as positive control were challenged with $0.4 \mathrm{ml}\left(1 \times 10^{9} \mathrm{CFU} / \mathrm{ml}\right)$ of $(\mathrm{Vi} L M)$ and negative group inoculated $\mathrm{S} / \mathrm{C}$ with $0.4 \mathrm{ml}$ of sterile PBS. All the animals were sacrificed and pieces of internal organs were fixed in $10 \%$ neutral buffer formalin for 72 hours for histopathological examination according to (9).

\section{Materials and Methods}

Mitomycin-C (2mg) was obtained from Sigma-Aldach Company. Chromosome aberration assay according to (10) and Micronucleus test according to the procedure of (11).Preparation of bone marrow cells was carried out according to the procedure produced by (12). Slide Preparation and Staining; according to the procedure of )13). Cytogenic tests include the estimation of mitotic Index assay, according to the formula according to (14).

\section{Results}

1-Cytogenic analysis: high mean values of CA and $\mathrm{MN}(7.90 \pm 0.54),(5.00 \pm 0.79)$ respectively was observed in animals inoculated with $\mathrm{MMC}$ at $(\mathrm{P} \leq 0.01)$ as comparing to animals immunized with CFLMAgs with mean values of CA $(0.04 \pm 0.02)$ and $\mathrm{MN}$ $(0.06 \pm 0.02)$, respectivly. WSLMAgs-treated MMC with mean values of $(0.04 \pm 0.02),(0.04 \pm 0.02)$ respectivly, non significant differences $(\mathrm{P} \leq 0.01)$ were observed in the mean values of non-immunized animals $(0.03 \pm 0.00)$ and $(0.03 \pm 0.00)$. The mean values of MI\% in animals immunized with WSLMAgs were $(3.16 \pm 0.05)$ and in WSLMAgs+MMC $(0.58 \pm 0.25)$, while in animals immunized with CFLMAgs were $(4.00 \pm 0.45)$ and in CFLMAgs+MMC $(1.52 \pm 0.34)$. All these results were higher than the values in animals treated with MMC (1.08 \pm 0.45$)$ and non-immunized non MMC treated (2.03 \pm 0.00$)$ animals, (Table$1)$. 
Proceeding of the Eleventh Veterinary Scientific Conference, 2012; 347 -354.

Table -1: percentages (\%) of $\mathrm{MI}, \mathrm{CA}$ and $\mathrm{MN}$ in animals immunized with viablevirulent $L M A g s$ and treated with MMC.

\begin{tabular}{|l|l|l|l|l|}
\hline & Groups & $\underline{\text { MI\% }}$ & $\underline{\text { CA\% }^{a}}$ & $\underline{\text { MN\% }}$ \\
\hline $\mathbf{( 1 )}$ & MMC. & $1.08 \pm 0.45^{\mathrm{a}}$ & $7.90 \pm 0.54^{\mathrm{a}}$ & $5.00 \pm 0.79^{\mathrm{a}}$ \\
\hline $\mathbf{2})$ & CFLMAgs. & $4.00 \pm 0.45^{\mathrm{c}}$ & $0.04 \pm 0.02^{\mathrm{c}}$ & $0.06 \pm 0.02^{\mathrm{c}}$ \\
\hline & CFLMAgs+ MMC. & $1.52 \pm 0.34^{\mathrm{b}}$ & $3.8 \pm 0.42^{\mathrm{b}}$ & $2.44 \pm 0.54^{\mathrm{b}}$ \\
\hline $\mathbf{( 3 )}$ & WSLMAgs. & $3.16 \pm 0.05^{\mathrm{c}}$ & $0.04 \pm 0.02^{\mathrm{c}}$ & $0.04 \pm 0.02^{\mathrm{c}}$ \\
\hline & WSLMAgs +MMC. & $0.58 \pm 0.25^{\mathrm{c}}$ & $0.62 \pm 25^{\mathrm{c}}$ & $0.48 \pm 0.21^{\mathrm{c}}$ \\
\hline $\mathbf{( 4 )}$ & Negative control. & $2.03 \pm 0.00^{\mathrm{d}}$ & $0.03 \pm 0.00^{\mathrm{d}}$ & $0.03 \pm 0.00^{\mathrm{d}}$ \\
\hline
\end{tabular}

$(a, b, c, d)$; different small Letters denoted the significant differences between different groups at $(\mathrm{P} \leq$ 0.01).

2:-Detection the concentrations of IFN-y (pg/ml):-The results in table-2 showed that the mean values of IFN-y in MMC treatment was lowest as comparing with animals immunized with CFLMAgs (647.29 194.73$)$ and WSLMAgs $(607.29 \pm 194.73)$, the results also showed that the levels of IFN-y in post-challenged with ViLM, and WSLMAgs+MMC was equal to

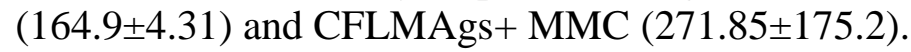

Table-2, Levels of IFN-y pg/ml in immunized animals with viable-virulent LMAgs and treated+MMC.

\begin{tabular}{|l|l|l|l|}
\hline & Concentrations of IFN-y & & \\
\hline & Group & Pre-challenged & Post-challenged \\
\hline $\mathbf{( 1 )}$ & MMC & $0.18 \pm 0.08^{\mathrm{e}}$ & $0.159 \pm 0.09^{\mathrm{e}}$ \\
\hline $\mathbf{2})$ & CFLMAgs & $647.29 \pm 194.73^{\mathrm{b}}$ & $560.78 \pm 346.24^{\mathrm{c}}$ \\
\hline & CFLMAgs MMC & & $271.85 \pm 175.2^{\mathrm{d}}$ \\
\hline $\mathbf{( 3 )}$ & WSLMAgs & $607.29 \pm 194.73^{\mathrm{b}}$ & $184.9 \pm 3.31^{\mathrm{e}}$ \\
\hline & WSLMAgs MMC & & $164.9 \pm 4.31^{\mathrm{e}}$ \\
\hline $\mathbf{( 4 )}$ & ViLM & $100.47 \pm 180.33^{\mathrm{d}}$ & $189.9 \pm 0.31^{\mathrm{e}}$ \\
\hline $\mathbf{( 5 )}$ & Negative control & \\
\hline
\end{tabular}

$(a, b, c, d)$; different small Letters denoted the significant differences between different groups at $(\mathrm{P} \leq$ 0.01).

3:-Detection IgG $_{1} \mathbf{~ p g} / \mathbf{m l}$ Antibody titers: The mean values of $\operatorname{IgG}_{1}$ in $M M C$ treatedanimals was lowest $(0.22 \pm 0.06)$ as comparing with control negative group (12.02 \pm 0.06$)$ and animals immunized with CFLMAgs $(22.23 \pm 0.19)$ and WSLMAgs (21.95 \pm 1.99$)$ (Table-3). Besides MMC treated-animals expressed lowest values of IgG1 $(0.06 \pm 0.01)$ post-challenged with ViLM as comparing with immunized WSLMAgs+MMC (15.90 \pm 0.76$)$ and CFLMAgs+MMC (22.95 \pm 1.9$)$, post-challenged with ViLM and control positive group (24.12 \pm 0.62$)$.

Table 3, Levels of $\operatorname{IgG}_{1}$ antibody titers $\mathrm{pg} / \mathrm{ml}$ in immunized animals with variant $\mathrm{Lm}$ Ags and treated with MMC.

\begin{tabular}{|l|l|l|l|}
\hline & Concentrations of & $\mathrm{IgG}_{1} \mathrm{pg} / \mathrm{ml}$ & \\
\hline & Group & $\underline{\text { Pre-challenged }}$ & Post-challenged $^{\mathrm{d}}$ \\
\hline $\mathbf{( 1 )}$ & MMC & $0.22 \pm 0.06^{\mathrm{d}}$ & $0.06 \pm 0.01^{\mathrm{d}}$ \\
\hline $\mathbf{( 2 )}$ & CFLMAgs & $22.64 \pm 0.03^{\mathrm{b}}$ & $25.08 \pm 0.02^{\mathrm{a}}$ \\
\hline & CFLMAgs+ MMC. & $21.95 \pm 1.99^{\mathrm{b}}$ & $22.95 \pm 1.9^{\mathrm{b}}$ \\
\hline $\mathbf{( 3 )}$ & WSLMAgs & & $22.95 \pm 1.99^{\mathrm{b}}$ \\
\hline & WSLMAgs+ MMC. & & $15.90 \pm 0.76^{\mathrm{c}}$ \\
\hline $\mathbf{( 4 )}$ & ViLM & $12.02 \pm 0.06^{\mathrm{c}}$ & $24.12 \pm 0.62^{\mathrm{a}}$ \\
\hline $\mathbf{( 5 )}$ & Negative control & \\
\hline
\end{tabular}

$(\mathbf{a}, \mathbf{b}, \mathbf{c}, \mathbf{d}, \mathbf{e})$, different small letters denoted the significant differences between different groups at $(\mathbf{P} \leq \mathbf{0 . 0 1})$. 4-Results of cytogenic analysis: The main structural shapes that induced in chromosomes of mice treated with $\mathrm{MMC}$ are; ring-shape, centric fusion and fragments, centromeric attenuation, chromatid deletion and micronucleus formation (figure-1\&2). 

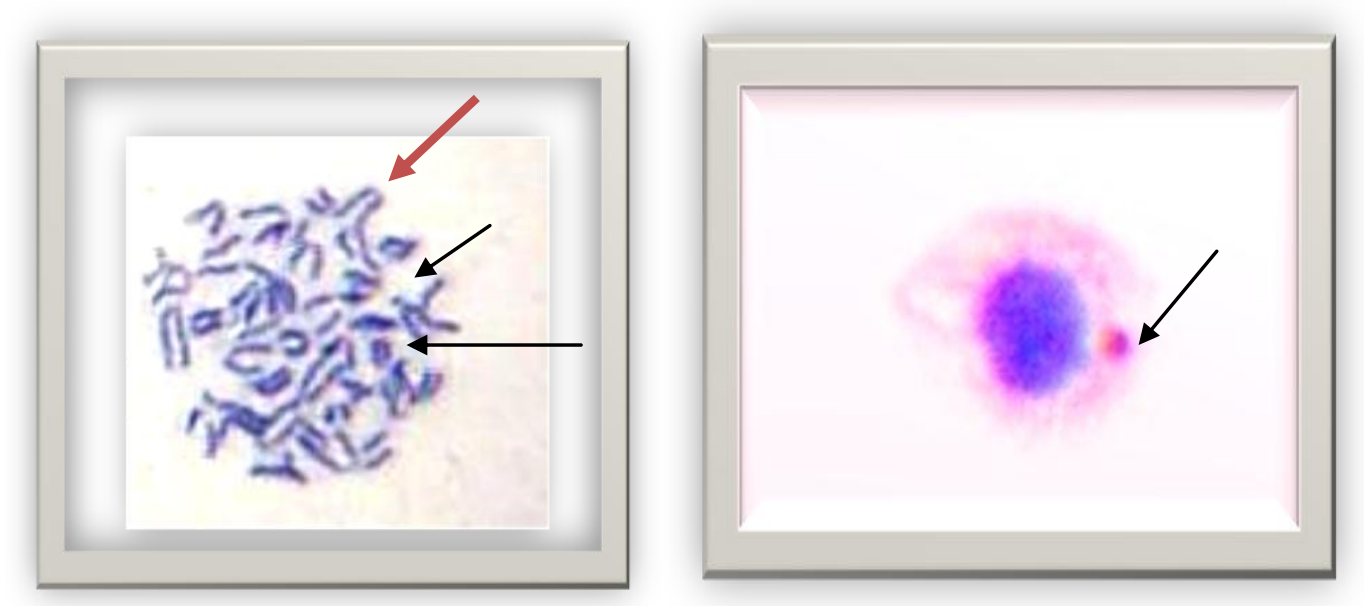

Figure-1:-different shapes of chromosome aberrations in mice treated-MMC; ring shape (long arrow), centromeric attenuation (red arrow) and centric fragment (short arrow).Figure-2:micronucleus (arrow) in mice treated- MMC (Geimsa stain, 100X).

5-Histopathological examination in control positive group and treated MMC-challenged with ViLM

Histopathological changes were similar but more sever in MMC-treated post-challenged with ViLM. The microscopic examinations of Lungs showed thickening of inter-alveolar septa due to fibrin deposition, infiltration of inflammatory cells and congestion of blood vessels (figure-3). In Liver; acute suppurative inflammation characterized by infiltration of neutophils in Liver parenchyma and lumen of congested B.Vs., as well as granulomatous lesions consisting from aggregation of macrophages in liver parenchyma with dilated sinuses in the animals infected with ViLM (figure-4). Small-multiple granulomatous lesions consisting from aggregation of macrophages and neutophils surrounded by necrotic area in liver parenchyma of animals treated with MMC.The white pulp of spleen showed moderate hyperplasia, congestion of red pulp and proliferation of megakaryocytic cells, mononuclear cells infiltration around congested blood vessels were seen in the kidney.

6- Immunized CFLMAgs and WSLMAgs-treated MMC challenged with ViLM: The Liver of immunized CFLMAgs+ViLM infection showed aggregation of mononuclear cells mainly Lymphocytes around congested blood vessels and in portal area. Small-multiple granulomatous lesions also reported in Liver parenchyma together with proliferation of kupffer cells, while immunized+MMC+infected animals showed large granulomatous lesions consisting from aggregation of neutophils and mononuclear cells surrounded by large coagulative necrotic area characterized by eosinophilic cytoplasm of hepatic cells with pyknotic or disappeared their nuclei (figure-5). Marked hyperplasia of lymphocytic cells in periarterial sheath and proliferation of mononuclear cells around the sinuses, in white pulp of spleen in immunized-infected animals, while in immunized MMC-infected animals showed moderate hyperplasia of white pulp. The Lungs of immunized animals showed mononuclear cells aggregation around blood vessels, while in immunized MMC+infected animals showed congestion of blood vessels with neutrophils in their lumens together with fibrin network deposition and inflammatory cells infiltration around blood vessels, mononuclear cells aggregation around blood vessels were reported in other examined organs. 


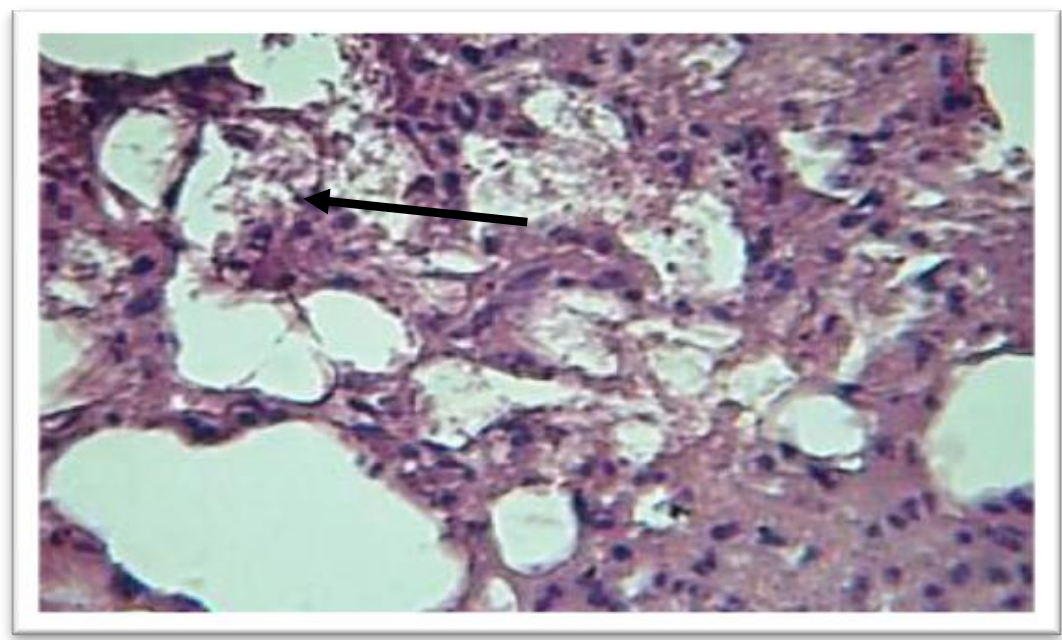

Figure-3:-Fibrin network in Lung alveoli (arrow) of mouse treated MMC, (H\&E stain, 40X).

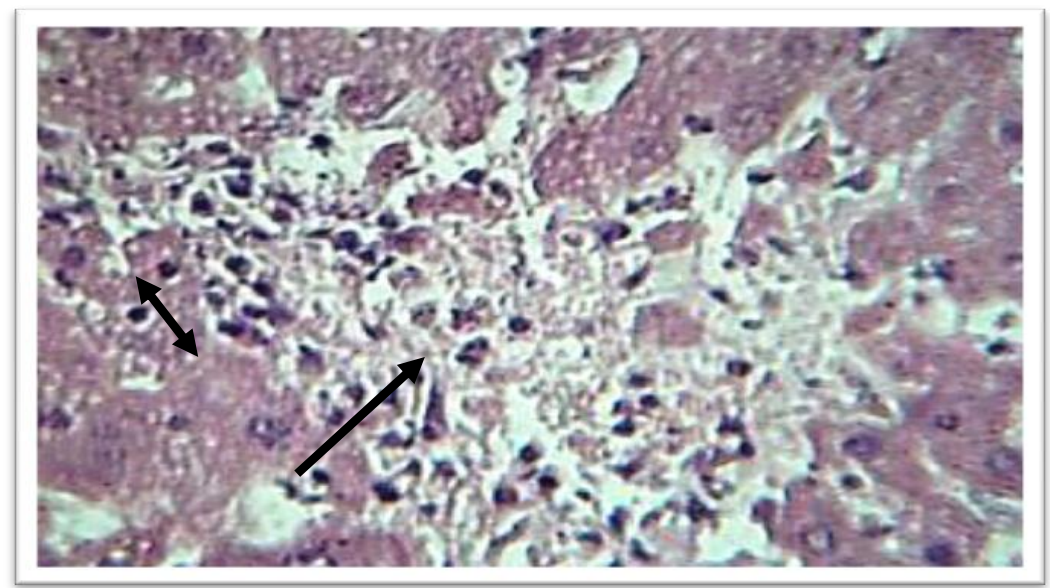

Figure-4:- Liver of mouse treated-MMC and Vi LM shows Large area of necrosis (arrow) and small-multiple granulomatous lesions $(\longleftrightarrow)(H \& E$ stain, 40X).

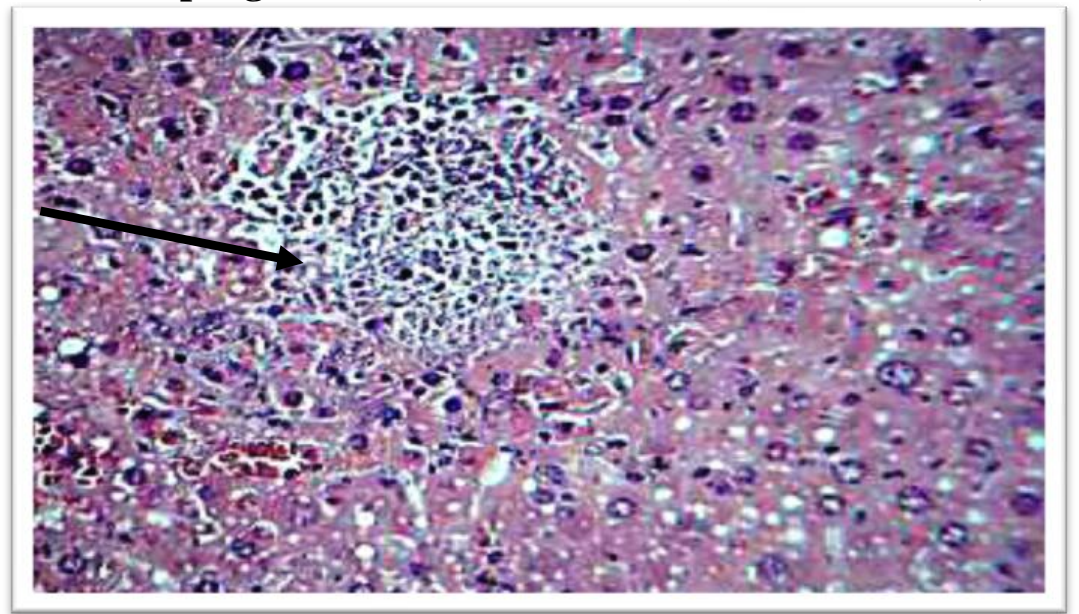

Figure-5: Granulomatous lesions in Liver of mice immunized CFLM+MMC challenged with ViLM $(\longrightarrow)$ (H\&E stain, 20X).

\section{Discussion}

1-Results of immune responses: The levels of IFN-y and $\mathrm{IgG}_{1}$ decreased by MMC in animals immunized with $L M$ antigens as comparing with non-immunized non-MMC treatment and immunized animals, were varied according to the type of immunizing antigen, may indicated MMC depressant effect on the immune responses, as (15) explained that the chemotherapeutic agents causes depression of immune system, moreover, our results showed 
high levels of IFN-y in immunized animals with WSLMAgs, may be indicated that immunization with WSLMAgs provided good immune responses against opportunistic $L M$ infection after treatment with MMC.

2-Cytogenetic results: In this study the concentrations of MMC induced cytotoxicity was equal to $0.4 \mathrm{mg} / \mathrm{ml}$. This evidence is in agreement with (5) who recorded that $0.05 \mathrm{mg} / \mathrm{ml}$ MMC for $24 \mathrm{hrs}$ not sufficient to induced mitotic inhibition and chromosomal aberrations but at concentrations of $2.0 \mathrm{mg} / \mathrm{ml}$ and above showed complete inhibition of mitotic activity and highly chromosomal aberrations. MMC inhibited mitotic index, increased chromosomal aberrations and micronuclei (16), the present study, reported that MMC induced chromosomal aberrations in mice. However, the main structural chromosome aberration shapes present in our study were; ring-shape, centromeric attenuation, centric fusion and fragments, also micronucleus formation, may be indicated MMC have direct cytotoxic effects on the chromosome chromatid and induce chromosome exchanges, which supported idea mentioned by (17) who reported that different MMC metabolic pathways resulted in ROS generation and some MMC metabolites may form cross-Links to adjacent guanines in DNA. Besides (18) suggested the heterochromatin-specific pairing following MMC treatment reflects the initiation of DNA cross-link repair and formation of exchanges.

In Immunized animals with various LMAgs and MMC-treated expressed low levels of chromosomal aberrations and micronucleus as comparing with non-immunized- MMC treated animals and these results are variable according to the type of immunizing antigens, the lowest percentages of CAs and MN reported in animals immunized with CFLMAgs and WSLMAgs, may indicated that the strength immune responses diminished the side effects of MMC on the host, therefore, the animals resists bacterial infection. According to these results we suggested the usage immunostimulater agents with MMC as antitumour chemotherapy which is in agreement with (19 and 20).

3-Pathological examination: Suppurative inflammatory reaction predominant in animals infected with $L M$ and more extensive in MMC treated+infected animals may be due to exposure to highly virulent $L M$ which overcome the innate immune system and disseminated to internal organs to induce tissue damage, These results are in agreement with (21\&22), who explained that virulent $L M$ disseminated via blood stream to internal organs and induced nonspecific inflammatory reaction by Listeriolysin $\mathrm{O}$, with destruction of endothelial cells of blood vessels (23). Multiple granulomatous lesions observed in liver parenchyma of MMC treated- infected animals and large granulomatous lesions in liver of non-treated+infected animals, may indicated the virulence $L M$ and strong body defense mechanisms to overwhelm infection (24). These evidences were in consistence with (25\&26), who explained that granulomatous reaction indicated strongest body defenses against virulent bacterial infection, moreover, the presence of multiple-small granulomatous lesions in treated+infected animals may be indicated that MMC depressed immune responses by the intensity of granulomatous reactions depend on immune response (27). Mild to moderated pathological lesions observed in internal organs of immunized post-challenged-LM and MMC treated+infection, as comparing to control positive group may be due to the stimulation of immune responses which were diminished duo to the side effects of MMC and coincidence with the results of cytogenic analysis and those of immune responses. Lymphoid tissue hyperplasia and mononuclear cells infiltration around blood vessels in internal organs of immunized animals post-challenge with $L M$ indicated that $L M A g s$ stimulated good immune responses, protected immunized animals against challenge with $\mathrm{Vi} L M$. These evidences were agreement with (28 and 29) who reported that lymphoid tissue hyperplasia indicated good immune responses.

\section{References}

1-Verweis, I. and Pinedo, H.M. (1996).Mitomycin C mechanism action, usefulness and limitation.Anti-Cancer Drugs, (1): 5-13. 
2-Crawford, E.D. (1996).Diagnosis and treatment of superficial bladder cancer: an update .Semin Urol Oncol.14:1-9.

3-Schnall, S. and Macdonald, J. S. (1995). MMC therapy in cancer.Oncology, 50:70-77.

4-Kelsen, D (1994).The use of chemotherapy in the treatment of advanced gastric cancer and pancreas cancer. Semin Oncol, 21:58-66.

7-Coia, L. (1993).The use of MMC in Esophageal Cancer Oncology, 50(1):53-62.

5-Keyes,S.R.,Inomis,R.,Digiovanna,M.P.,Pritsus,O.A.,Bockwell,S. and Sartorelli,A.O. (1991). Cytotoxicity and DNA cross-links produced by Mitomycin analogs in aerobic and hypoxic EMT6 cells. Cancer Commun, (3): 351-356.

6- Morad, M., Ionason, I. and Lindsten, I. (1973).Distribution of Mitomycin C induced breaks on human chromosomes. Hereditas, (74): 273-282.

7- Miller,T.P.; McMahon, L.J. and Livingston, R.B.(1980).Extensive adenocarcinoma and large cell undifferentiated carcinoma of the lung treated with 5- FU,vincristine and MMC. Cancer Treat Rep, (64): 1241-1245.

8-Yaseen, N.Y. (1990). Cytogenetic study on human colorectal cancer cells. PhD. Thesis, University of Sheffield.

9-Luna, L.G. (1968). Manual of histological staining methods of the armed forces institute of Pathology. $3^{\text {rd }}$ Ed.Mc graw-Hill. New York.

10-Schmid, W. (1979). The micronucleus test. Hand book of mutagenecity test procedures, Elsevier, North- Holland, Biomedical Press, Netherland, PP:236- 242.

11-Allen, J.W.; Shuler, C.F.; Meners, R.W. and Olatt, S.A. (1997).A simplified technique for in vivo analysis of sister chromatid exchange using 5-bromodeoxy uridine tablets.Cytogenet.Cell.Genet, (18): 231-237.

12- Haaf, T.; Steinlein, K. and Schmid, W. (1986). Preferential somatic pairing between homologous heterochromatic regions of human chromosomes. Am.J.Hum.Gent, (38):319-329. 13-Brogger, A. and Johansen, I.(1972). A model for the production of chromosome damage by Mitomycin C.Chromosoma (Berl), (38): 95-104.

14-Chattopadhyay, A.; Deb, S. and Chatterjee, A. (1999). A modulation of the clastogenic activity of y-irradiation in buthionine sulphoximine-mediated glutathione depleted mammalian cells. Int J Radiat Biol., 75(10):1283-1291.

15-Mackall, C.L. (2000).T-cell immunofifficiency following cytotoxic antineoplastic therapy: A review. Stem Cells, (18): 10-18.

16-Sparreboom, A., Nooter, K. and Verweij, J. (2002).Mechanisms of Action of Cancer Chemotherapeutic Agents: Antitumour Antibiotics. The cancer Handbook $1^{\text {st }}$ Edition. Edited by Malcolm R.Alison, John Wiley and Sons, Ltd.

17-Cohen, M.M. and Shaw, M.W. (1965). Effects of Mitomycin-C on Human Chromosomes. J.Cell Biol, (23):386-395.

18-Doll, D.C., Weiss, R.B. and Issell, B.F.(1985). Mitomycin: Ten Years after Approval for Marketing. J. Clin. Oncol, 3: 276-286.

19-Brewen, J. G. and Presto, R. J. (1978). Analysis of chromosome aberrations n mammalian germ cells. In Chemical Principles and methods for their detection. Plenum press. New York. (5): 127-150.

20-Oliveira, N.G., Rodrigues, A.S., Chaveca, T. and Rueff, J. (1997). Induction of an adaptive response to quercetin, Mitomycin $\mathrm{C}$ and hydrogen peroxide by low doses of quercetin in V79 Chinese hamster cells. Mutagenesis, 12 (6): 457-62.

21Abdelhalim, H.I., Natarajan, A.T., Mullenders, L.H.F. and Boei, W.A. (2005).MMC induced pairing of heterochromatin reflects initiation of DNA repair and chromatid exchange formation. J. Cell Science, vol 118, PP: 1757-1767.

22-Snottakke, Y.A. and Fulzele, R.R. (2009).Cytogenetic study on genotoxicity of antitumour-antibiotic Mitomycin C. Biomedical research, 20(1), PP: 40-44. 
23-Chaussabel, D., R.T.; Semnani, M. A.; McDowell, D.; Sacks, A. Sher, and T. B. Nutman. (2003). Unique gene expression profiles of human macrophages and dendritic cells to phylogenetically distinct parasites. Blood, (102): 672-681.

24-Antonia, S.J., Mirza, N., Fricke, I., et al., (2006). Combination of p53 cancer vaccine with chemotherapy in patients with extensive stage small cell lung cancer. Clin Cancer Rep, (12): 878-87.

25- Finn, O.J.Ph.D. (2008).Cancer Immunology. N. Eng. J. Med., 358:2704-15.

26-Vazquez-Boland, J.A.; Kuhn, M.; Berche, D.; Chakraborty, T.; Domingnes-Bernal, G.; Geobel, W.; Gonzales-Zorn, B.; Wehland, J. and Kreft, J. (2001). Listeria pathogenesis and molecular virulence determinants. Clin. Microbiol. Rev, (14): 584-640.

27- Riley, L.K. and Robertson, D.C. (1984).Ingestion and intercellular survival of Listeria monocytogenes in human and bovine polymorphonuclear leukocytes. Infection Immunity, (46): 224-230.

28- Dunn, P.L. and North, R.J. (1996). Persistent Infection with Virulent but not avirulent Listeria monocytogenes in the lungs of mice causes progressive pathology. J.Med.Micro, (45): 103-104.

29-Al-Zoobadi, O.S.M (2006).Comparative study of vaccines effect prepared from Listeria monocytogenes in immunization of laboratory animals/Immunopathological study. MSc. Thesis, Veterinary College / Baghdad University. 